\title{
CD9 Gene
}

National Cancer Institute

\section{Source}

National Cancer Institute. CD9 Gene. NCI Thesaurus. Code C101154.

This gene is involved in both cell adhesion and platelet function. 